University of Nebraska - Lincoln

DigitalCommons@University of Nebraska - Lincoln

Biological Systems Engineering: Papers and

Publications

Biological Systems Engineering

2006

\title{
Variable Upper and Lower Crop Water Stress Index Baselines for Corn and Soybean
}

J. O. Payero

University of Nebraska-Lincoln, jpayero@clemson.edu

Suat Irmak

University of Nebraska-Lincoln, suat.irmak@unl.edu

Follow this and additional works at: https://digitalcommons.unl.edu/biosysengfacpub

Part of the Biological Engineering Commons

Payero, J. O. and Irmak, Suat, "Variable Upper and Lower Crop Water Stress Index Baselines for Corn and Soybean" (2006). Biological Systems Engineering: Papers and Publications. 50.

https://digitalcommons.unl.edu/biosysengfacpub/50

This Article is brought to you for free and open access by the Biological Systems Engineering at DigitalCommons@University of Nebraska - Lincoln. It has been accepted for inclusion in Biological Systems Engineering: Papers and Publications by an authorized administrator of DigitalCommons@University of Nebraska Lincoln. 
Published in Irrigation Science 25 (2006), pp. 21-32; doi: 10.1007/s00271-006-0031-2

Copyright (c) 2006 Springer-Verlag. Used by permission.

Submitted September 26, 2005; accepted February 7, 2006; published online March 3, 2006.

Communicated for Irrigation Science by S. Raine.

\title{
Variable Upper and Lower Crop Water Stress Index Baselines for Corn and Soybean
}

\author{
J. O. Payero \\ West Central Research and Extension Center, University of Nebraska-Lincoln, \\ 461 West University Drive, North Platte, NE 69101, USA \\ S. Irmak \\ Department of Biological Systems Engineering, University of Nebraska-Lincoln, \\ 234 L. W. Chase Hall, Lincoln, NE 68583-0726, USA \\ Corresponding author - J. O. Payero, email jpayero2@unl.edu
}

\begin{abstract}
Upper and lower crop water stress index (CWSI) baselines adaptable to different environments and times of day are needed to facilitate irrigation scheduling with infrared thermometers. The objective of this study was to develop dynamic upper and lower CWSI baselines for corn and soybean. Ten-minute averages of canopy temperatures from corn and soybean plots at four levels of soil water depletion were measured at North Platte, Nebraska, during the 2004 growing season. Other variables such as solar radiation $\left(R_{\mathrm{s}}\right)$, air temperature $\left(T_{\mathrm{a}}\right)$, relative humidity $(\mathrm{RH})$, wind speed $(u)$, and plant canopy height $(h)$ were also measured. Daily soil water depletions from the research plots were estimated using a soil water balance approach with a computer model that used soil, crop, weather, and irrigation data as input. Using this information, empirical equations to estimate the upper and lower CWSI baselines were developed for both crops. The lower baselines for both crops were functions of $h$, vapor pressure deficit (VPD), $R_{\mathrm{s}^{\prime}}$ and $u$. The upper baselines did not depend on VPD, but were a function of $R_{\mathrm{s}}$ and $u$ for soybean, and $R_{\mathrm{s}^{\prime}} h$, and $u$ for corn. By taking into account all the variables that significantly affected the baselines, it should be possible to apply them at different locations and times of day. The new baselines developed in this study should facilitate the application of the CWSI method as a practical tool for irrigation scheduling of corn and soybean.
\end{abstract}

\section{Introduction}

Irrigated agriculture is a major component in Nebraska's economy, producing an annual income of about US\$5 billion. In Nebraska, around 33\% of cropland is irrigated (Johnson 2001), which is above the national average of 11\% (Postel 1999). The most important irrigated crop in the state is corn, followed by soybean. Sources of irrigation water include both surface and groundwater. Groundwater is mainly pumped from the Ogallala formation of the High Plains Aquifer, which underlies parts of eight states. Irrigation water supplies in many areas of Nebraska are declining, requiring farmers to use water more efficiently. Despite current pressures and incentives to increase irrigation efficiency, most farmers in $\mathrm{Ne}$ braska still schedule irrigation empirically. Although this behavior is in part due to the fact that until recently, water has traditionally been abundant and inexpensive, it is also due to a lack of easily applicable and scientifically based irrigation scheduling methods and tools. A potentially simple way to schedule irrigation is by measuring crop canopy temperature using infrared thermometers.

This method is based on the fact that the difference between canopy and air temperatures $\left(T_{c}-T_{a}\right)$ increases when crops are under water stress, in response to decreased evapotranspiration, which serves as a cooling mechanism for the crop (Wolpert 1962; Gates 1964; Linacre 1964; Conaway and van Bavel 1967; Fuchs and Tanner 1966; Carlson et al. 1972). It is known that $\left(T_{c}-T_{a}\right)$ is linearly related to air vapor pressure deficit (VPD) (Idso et al. 1981). The relationship, however, changes with soil water content (Geiser et al. 1982; Idso et al. 1977; Jackson et al. 1977; Blad et al. 1981, Ehrler 1973; Ehrler et al. 1978) and weather conditions (Payero et al. 2005a; Jackson et al. 1981; and Jackson 1982). Idso et al. (1981) showed that a lower and upper baseline can be established empirically 
for non-water-stressed and water-stressed crop conditions, respectively. They defined the crop water stress index (CWSI) as

$$
\begin{aligned}
\text { CWSI }= & {\left[\left(T_{\mathrm{c}}-T_{\mathrm{a}}\right)_{\mathrm{m}}-\left(T_{\mathrm{c}}-T_{\mathrm{a}}\right)_{\mathrm{LB}}\right] \div\left[\left(T_{\mathrm{c}}-T_{\mathrm{a}}\right)_{\mathrm{UB}}\right.} \\
& \left.-\left(T_{\mathrm{c}}-T_{\mathrm{a}}\right)_{\mathrm{LB}}\right]
\end{aligned}
$$

where the subscripts $\mathrm{m}, \mathrm{LB}$, and UB refer to the $\left(T_{\mathrm{c}}-T_{\mathrm{a}}\right)$ values for the measured, lower baseline, and upper baseline, respectively. The CWSI is commonly used to schedule irrigation using infrared thermometers (Stegman 1986; Yazar et al. 1999; Irmak et al. 2000). Jackson et al. (1981) and Jackson (1982) established the theoretical basis for the CWSI. They showed that the LB was a function of net radiation, crop resistances (both aerodynamic and surface) and VPD, while the UB was a horizontal line that depended on available energy and crop aerodynamic properties. This theoretical approach requires knowing the crop resistance properties and net radiation, in addition to measured values of $\left(T_{c}-T_{a}\right)$ and VPD, which makes it difficult to apply the theoretical method in practice. For this reason, most researchers have preferred to use the empirical CWSI approach, which requires locally calibrated baselines.

Most researchers, however, assume that weather conditions are constant if the measurements required to locally calibrate the baselines are made close to noon and under clear sky conditions. This assumption is problematic because it is well known that weather conditions do change with location, time of day and day of the year, and the baselines for the same crop will consequently change with weather conditions (Payero et al. 2005a; Zolnier et al. 2001; Jensen et al. 1990). Researchers from different places have, therefore, reported different baselines for the same crop. For instance, Figure 1 shows the different lower baselines reported for corn. The upper baseline is also affected by weather conditions. For instance, for corn, researchers have reported upper baselines of $3^{\circ} \mathrm{C}$ (Shanahan and Nielsen 1987; Nielsen and Gardner 1987), $5^{\circ} \mathrm{C}$ (Steele et al. 1994), and $4.6^{\circ} \mathrm{C}$ (Irmak et al. 2000). Sadler et

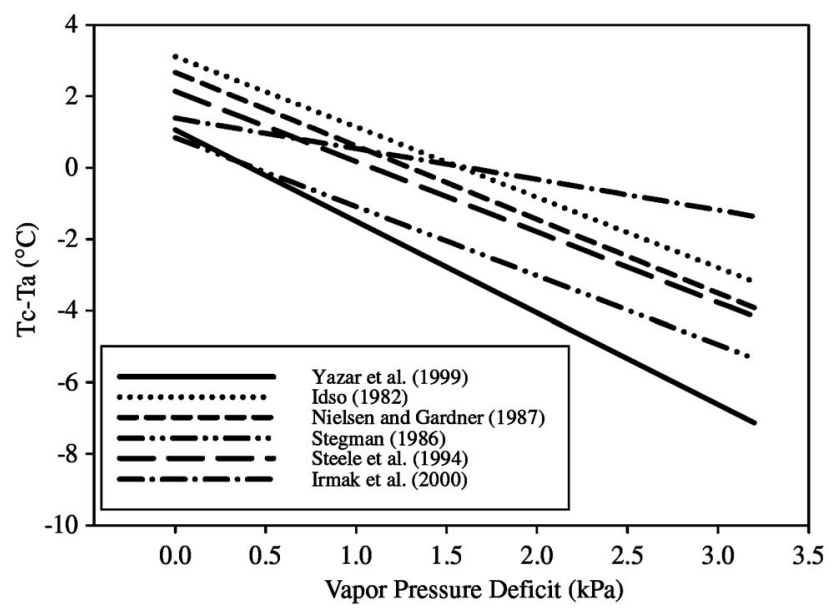

Figure 1. Non-water-stressed baselines reported by several researchers for corn. al. (2000), however, reported values of $\left(T_{c}-T_{a}\right)>10^{\circ} \mathrm{C}$, and Jensen et al. (1990) found $\left(T_{c}-T_{a}\right)$ values for several crops as high as $8^{\circ} \mathrm{C}$ when solar radiation was high, and values approaching zero or even negative when solar radiation was low.

The lack of transferability of the baselines, together with the restriction of having to make required measurements close to noon and under clear sky conditions, are major drawbacks of using the empirical CWSI method for irrigation scheduling (Alves and Pereira 2000). These problems have prevented farmers for decades from using this method. The objective of this study was to develop variable upper and lower CWSI baselines for corn and soybean.

\section{Materials and methods}

\section{Site description}

Field data for this study were collected from corn and soybean plots during 2004 at North Platte, Nebraska $\left(41.1^{\circ} \mathrm{N}, 100.8^{\circ} \mathrm{W}, 861 \mathrm{~m}\right.$ above sea level). The field experiment was conducted at the University of NebraskaLincoln West Central Research and Extension Center. The soil at North Platte is a Cozad silt loam (Fluventic Haplustolls) with field capacity of $0.29 \mathrm{~m}^{3} \mathrm{~m}^{-3}$ and permanent wilting point of $0.11 \mathrm{~m}^{3} \mathrm{~m}^{-3}$ (Klocke et al. 1999). The corn variety Renze $9363 \mathrm{Bt}$ RR was planted at 0.76$m$ row spacing on May 10, and harvested on November 15 . The soybean variety Renze $2600 \mathrm{RR}$ was also planted at $0.76-\mathrm{m}$ row spacing on May 21, and harvested on October 5 . Both crops were irrigated using a solid-set sprinkler system that was arranged in a $12.2 \times 12.2 \mathrm{~m}$ grid. Four plots of each crop were used in the experiment. Each experimental plot was surrounded by a "border" plot of the same size to avoid edge effects on the experimental plots. The inclusion of "border" plots effectively separated irrigation treatments. Sprinkler heads were installed at the four corners of each plot on 3.35- $\mathrm{m}$ risers.

For each crop, data were collected from four different plots, which received different irrigation treatments, including a dryland treatment. These plots were part of a larger deficit irrigation experiment that included nine treatments (T1-T9) for corn and eight treatments (T1-T8) for soybean (Figure 2). The treatments included in this experiment were $\mathrm{T} 1, \mathrm{~T} 3, \mathrm{~T} 4$, and $\mathrm{T} 9$ for corn, and T1, T3, T7, and $\mathrm{T} 8$ for soybean. These plots included a wide range of stress levels and were also conveniently located at the same distance from a center plot, which facilitated measuring canopy temperature. Amounts and timings of irrigation events applied to the different irrigation treatments included in this study are given in Table 1. Seasonal irrigation depths for the irrigated treatments ranged from 39 to $161 \mathrm{~mm}$ for corn, and from 19 to $162 \mathrm{~mm}$ for soybean. The dryland treatments (T8 for soybean and T9 for corn) received no irrigation. 
Figure 2. Plot layout of field experiment at North Platte. Canopy temperature data for each crop were collected from the shaded plots. The number indicates the plot number and the irrigation treatment is indicated in parenthesis. The plots with no numbers are the "border" plots. The " $x$ " indicates the location of the tripod with the datalogger, multiplexer, and meteorological sensors.

\section{Field measurements}

Measurements included canopy temperature, air temperature, relative humidity $(\mathrm{RH})$, wind speed, solar radiation, and plant canopy height. Canopy temperature was measured for each plot, while average values for each crop were measured for all the other variables. Daily average canopy heights for each crop were estimated from weekly measurements. For each crop, the four experimental plots were located at the same distance from a center "border" plot (Figure 2). A tripod with an environmental enclosure housing a datalogger and a mul-

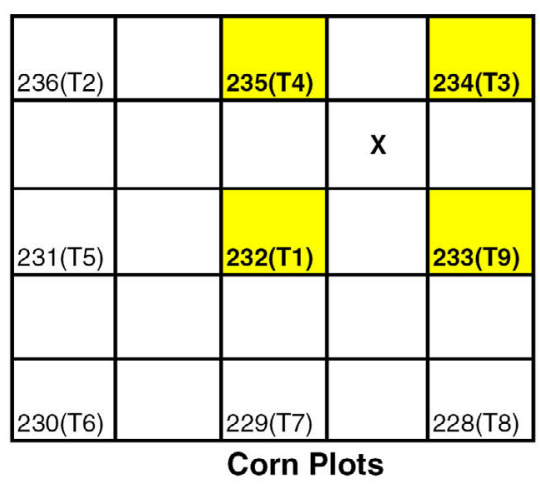

Table 1. Irrigation ( $\mathrm{mm}$ ) applied to soybean and corn at North Platte during 2004 for each irrigation treatment (T1-T9).

\footnotetext{
a Percentage of $\mathrm{ET}_{\mathrm{w}}$ is the percent of seasonal crop evapotranspiration when soil water is not limiting that was supplied by irrigation
}

\begin{tabular}{|c|c|c|c|c|}
\hline \multicolumn{5}{|l|}{ Soybean } \\
\hline Date & $\mathrm{T} 1$ & T3 & $\mathrm{T} 7$ & T8 (Dryland) \\
\hline $8 / 9 / 04$ & 43.9 & - & - & - \\
\hline $8 / 12 / 04$ & 7.9 & 16.0 & - & - \\
\hline $8 / 13 / 04$ & - & 13.2 & - & - \\
\hline $8 / 17 / 04$ & 35.8 & - & - & - \\
\hline $8 / 20 / 04$ & - & - & 18.8 & \\
\hline $8 / 23 / 04$ & 26.7 & - & - & - \\
\hline $8 / 24 / 04$ & - & 27.7 & - & - \\
\hline $8 / 25 / 04$ & - & 11.2 & - & - \\
\hline $9 / 7 / 04$ & - & 11.2 & - & - \\
\hline $9 / 8 / 04$ & 47.8 & - & - & - \\
\hline Total & 162.1 & 79.2 & 18.8 & 0.0 \\
\hline Percentage of $\mathrm{ET}_{\mathrm{w}}{ }^{\mathrm{a}}$ & $28 \%$ & $14 \%$ & $3 \%$ & $0 \%$ \\
\hline \multicolumn{5}{|l|}{ Corn } \\
\hline Date & $\mathrm{T} 1$ & $\mathrm{~T} 3$ & $\mathrm{~T} 4$ & T9 (Dryland) \\
\hline $8 / 9 / 04$ & 11.7 & - & - & - \\
\hline $8 / 11 / 04$ & 39.1 & - & - & - \\
\hline $8 / 12 / 04$ & - & 10.4 & 10.4 & - \\
\hline $8 / 13 / 04$ & - & - & 22.6 & - \\
\hline $8 / 17 / 04$ & 35.8 & - & - & - \\
\hline $8 / 19 / 04$ & - & - & - & - \\
\hline $8 / 23 / 04$ & 26.7 & - & - & - \\
\hline $8 / 24 / 04$ & - & 28.2 & 28.2 & - \\
\hline $8 / 25 / 04$ & - & - & - & - \\
\hline $9 / 7 / 04$ & - & - & 18.8 & - \\
\hline $9 / 8 / 04$ & 47.8 & - & 5.6 & - \\
\hline Total & 161.0 & 38.6 & 85.6 & 0.0 \\
\hline Percentage of $\mathrm{ET}_{\mathrm{w}}$ & $21.2 \%$ & $5.1 \%$ & $11.3 \%$ & $0.0 \%$ \\
\hline
\end{tabular}


Table 2. Technical specifications for the IRTS-P precision infrared thermocouple sensor (Apogee Instruments Inc., Logan, UT).

\begin{tabular}{ll}
\hline $\begin{array}{l}\text { Power requirements } \\
\text { Operating environment }\end{array}$ & $\begin{array}{l}\text { None: self-powered } \\
\text { Designed for continuous } \\
\text { outdoor use } \\
\pm 0.5^{\circ} \mathrm{C}\end{array}$ \\
Accuracy & $0.05^{\circ} \mathrm{C}$ from 15 to $35^{\circ} \mathrm{C}$ \\
Repeatability & Less than $1 \mathrm{~s}$ \\
Response time & 2 type-K thermocouple wires \\
Output signal & Silicon lens \\
Optics & $6.5-14 \mu \mathrm{m}$ \\
Wavelength range & $6 \mathrm{~cm}$ long by $2.3 \mathrm{~cm}$ diameter \\
Dimensions & Less than $100 \mathrm{~g}$ \\
Mass & $3: 1$ (Distance from target: \\
Field of view & target diameter) \\
\hline
\end{tabular}

the tripod above all other instruments to make sure it was never shaded. Air temperature and $\mathrm{RH}$ were measured with a HMP45C sensor (Campbell Scientific, Logan, UT) installed at the same height as the anemometer. The air temperature and RH measurements were used to calculate the VPD of the air as (Allen et al. 1998):

$$
\begin{aligned}
& e_{\mathrm{s}}=0.6108 \times \exp [17.27 \mathrm{~T} /(T+237.3)] \\
& e_{\mathrm{a}}=e_{\mathrm{s}} \times(\mathrm{RH} / 100) \\
& \mathrm{VPD}=e_{\mathrm{s}}-e_{\mathrm{a}}
\end{aligned}
$$

where $e_{\mathrm{s}}$ is the saturation vapor pressure $(\mathrm{kPa}), T$, the mean air temperature $\left({ }^{\circ} \mathrm{C}\right), \mathrm{RH}$, the relative humidity of the air (\%), and, VPD, the vapor pressure deficit (kPa).

Sixteen infrared thermometers were used to measure canopy temperature. The temperature measurements started on July 15, when the crops had reached full canopy cover to avoid measuring the temperature of the soil surface, and continued until the crops matured. For each crop, canopy temperature from each of the four plots was measured using two infrared thermometers per plot. The infrared thermometers used in this study were of the model IRTS-P precision infrared thermocouple sensor (Apogee Instruments, Inc., Logan, UT). Technical specifications for the IRTS-P sensor are shown in Table 2. The infrared thermometers were installed approximately one meter above the maximum plant canopy height at a $45^{\circ}$ angle, one pointing east and the other pointing west. The average of the two sensors was used for the analyses. A mount made of $1.9 \mathrm{~cm}$ $\left(3 / 4^{\prime \prime}\right)$ PVC pipe and fittings was constructed to house the two infrared thermometers in each plot and to be able to install them above the canopy (Figure 3). The mount was shaped in form of $\mathrm{a}$ " $\mathrm{T}$ " and a steel pipe was used as a riser. The riser was supported by a T-post that was driven in the ground. The infrared thermometers were placed inside the PVC mount for protection, and to reduce temperature variations of the body of the sensors that could affect their accuracy, as reported by Bugbee et al. (1998).

The infrared thermometers were sampled using a $21 \times$ datalogger (Campbell Scientific, Logan, UT). The thermometers were connected to the datalogger via an

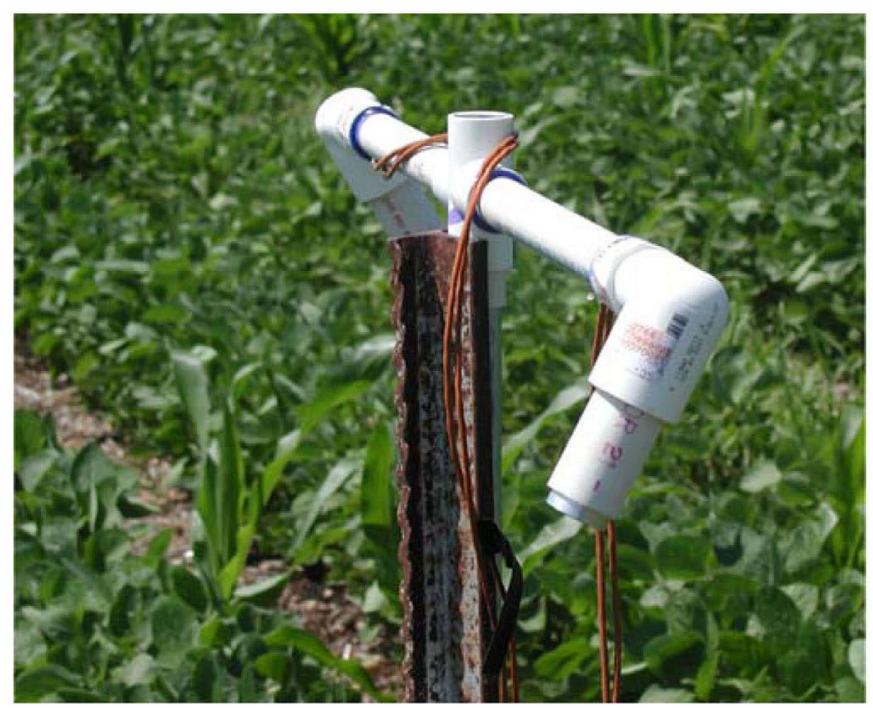

Figure 3. Field setup used to install two infrared thermometers above the crop canopy. One sensor was pointing east and another was pointing west.

AM16/32 multiplexer (Campbell Scientific, Logan, UT). Both the temperature of the target (canopy) and the body of each sensor were measured from each infrared thermometer using Type K (Chromel-Alumel) thermocouple wires. The temperature from each thermocouple was sampled every minute by measuring the differential voltage between the two thermocouple wires. Data from the infrared thermometers and from all the other instruments were averaged and stored every $10 \mathrm{~min}$. Data were downloaded from the datalogger to a laptop computer approximately twice a week.

Daily soil water depletion in the crop root zone was estimated using a soil water balance approach. A computer program was written in Microsoft Visual Basic ${ }^{\circledR}$ to model the daily soil water status. Input to the program included daily weather data, rainfall, irrigation, the water content in the soil profile at crop emergence, and crop-specific and site-specific information such as planting date, maturity date, soil parameters, and maximum rooting depth. Based on these inputs, the water balance in the crop root zone was calculated on a daily basis. The water content in the soil profile at crop emergence was measured using the neutron scattering method. Soil water readings were taken from aluminum access tubes installed at the center of the plot in each irrigation treatment. Readings were taken at 0.3-m depth increments to a depth of $1.8 \mathrm{~m}$. Daily crop evapotranspiration was calculated using the procedure presented in FAO-56 (Allen et al. 1998; Wright 1982). Since this is a long procedure, it will not be repeated here and readers are referred to the original sources for details. According to the FAO-56 procedure, crop evapotranspiration can be obtained as the product of the evapotranspiration of a reference crop $\left(\mathrm{ET}_{0}\right)$ (a grass reference was used in this study) and a crop coefficient $\left(K_{c}\right) . \mathrm{ET}_{0}$ is calculated us- 
ing the weather data as input to the Penman-Monteith equation and the $K_{\mathrm{c}}$ is used to adjust the estimated $\mathrm{ET}_{0}$ for the reference crop to that of other crops at different growth stages and growing environments. In this study, the dual crop coefficient approach was used to separate the two components of evapotranspiration (evaporation, $E$, and transpiration, $T$ ), taking basal $K_{\mathrm{c}}$ values for both crops from Table 17 in FAO-56. This procedure linearly reduced crop evapotranspiration when the available soil moisture in the crop root zone was below $50 \%$, which was used to quantify the effect of water stress on crop water use. The dual crop coefficient procedure also accounts for the sharp increases of the evaporation component due to a wet soil surface following a rain or irrigation. Weather data used as input to the program was obtained from an automatic weather station located at the research station. The weather station was part of the High Plains Regional Climate Center (HPRCC) weather network. Daily weather data were downloaded from the HPRCC web site - http://www.hprcc.unl.edu/home. $\underline{\mathrm{html}}-$, including daily maximum and minimum air temperature, $\mathrm{RH}$, wind speed, rainfall, and solar radiation. The computer program calculated the daily soil water balance for each $0.30 \mathrm{~m}$ soil layer and then calculated the daily $\%$ root zone depletion on day $i\left(\% \operatorname{Dep}_{i}\right)$ as

$$
\% \operatorname{Dep}_{i}=\left(\operatorname{Dep}_{i} / \mathrm{TAW}_{i}\right) \times 100
$$

where $\operatorname{Dep}_{i}$ is the soil water depletion in the crop root zone on day $i(\mathrm{~mm}), \mathrm{TAW}_{i}$, the maximum amount of water that can be depleted from the root zone on day $i(\mathrm{~mm})$, which increases during the growing season as roots grow.

\section{Calibration of infrared thermometers}

The manufacturer of the type of infrared thermometers used in this study recommends correcting the temperatures measured by the infrared sensors to account for differences in the apparent target temperature and the sensor body temperature, using the procedure proposed by Bugbee et al. (1998) as

$$
\begin{aligned}
& \mathrm{CTT}=(\mathrm{ATT}-\mathrm{SEC}) \\
& \mathrm{SEC}=\left(0.25 / P_{\mathrm{sb}}\right) \times\left[\left(\left(\mathrm{ATT}-H_{\mathrm{sb}}\right)^{2}\right)-K_{\mathrm{sb}}\right]
\end{aligned}
$$

where CTT is the corrected target (canopy) temperature $\left({ }^{\circ} \mathrm{C}\right)$, ATT, the apparent target (canopy) temperature $\left({ }^{\circ} \mathrm{C}\right)$, SEC, the sensor error correction $\left({ }^{\circ} \mathrm{C}\right)$, and $P_{\mathrm{sb}^{\prime}}, H_{\mathrm{sb}^{\prime}}$ and $K_{\mathrm{sb}}$ are generic (sensor independent) calibration coefficients that can be calculated as a function of sensor body temperature $(\mathrm{SB})\left({ }^{\circ} \mathrm{C}\right)$ using second degree polynomials as

$$
\begin{aligned}
& P_{\mathrm{sb}}=26.168+2.8291(\mathrm{SB})-0.03329\left(\mathrm{SB}^{2}\right) \\
& H_{\mathrm{sb}}=5.8075-0.08016(\mathrm{SB})+8.49 \mathrm{e}^{-3}\left(\mathrm{SB}^{2}\right) \\
& K_{\mathrm{sb}}=-85.943+11.740(\mathrm{SB})+0.08477\left(\mathrm{SB}^{2}\right)
\end{aligned}
$$

In this study, however, to improve accuracy, a calibration function was developed for each infrared thermometer. The calibration was performed at the end of the growing season after the sensors had been in the field for several months. The sensors and recording system were dismounted and transported to the laboratory. The sensors were still connected to the recording system, and care was taken to conserve the same datalogger program used in the field to perform the calibration. During the calibration, however, the sampling interval in the datalogger program was changed from $1 \mathrm{~min}$ to $10 \mathrm{~s}$, to be able to record the rapid temperature fluctuations of the calibration source used as the temperature standard.

The calibration was performed using a model 1000 calibration source (Everest Interscience Inc., Tucson, AZ). The Black body surface of the calibration source had been prepared using high emissivity aluminum oxide, with a configuration that uses re-entrant concentric rings. The calibration was conducted inside a laboratory hood (Figure 4). The temperature inside the hood and that of the black body were increased using a portable electric heater. For temperatures below ambient temperature, the calibration source was placed inside a refrigerator until its temperature was just above the freezing temperature. The temperature of the black body was then allowed to decrease or increase, and readings with the infrared thermometers were taken at different temperatures, ranging between approximately $5-45^{\circ} \mathrm{C}$, which included the temperatures that would normally occur in the field during the period of the study. Temperatures of the black body, and the infrared thermometer readings, including the temperature of the body of the sensors, were recorded. At each temperature, three readings were recorded with each infrared thermometer.

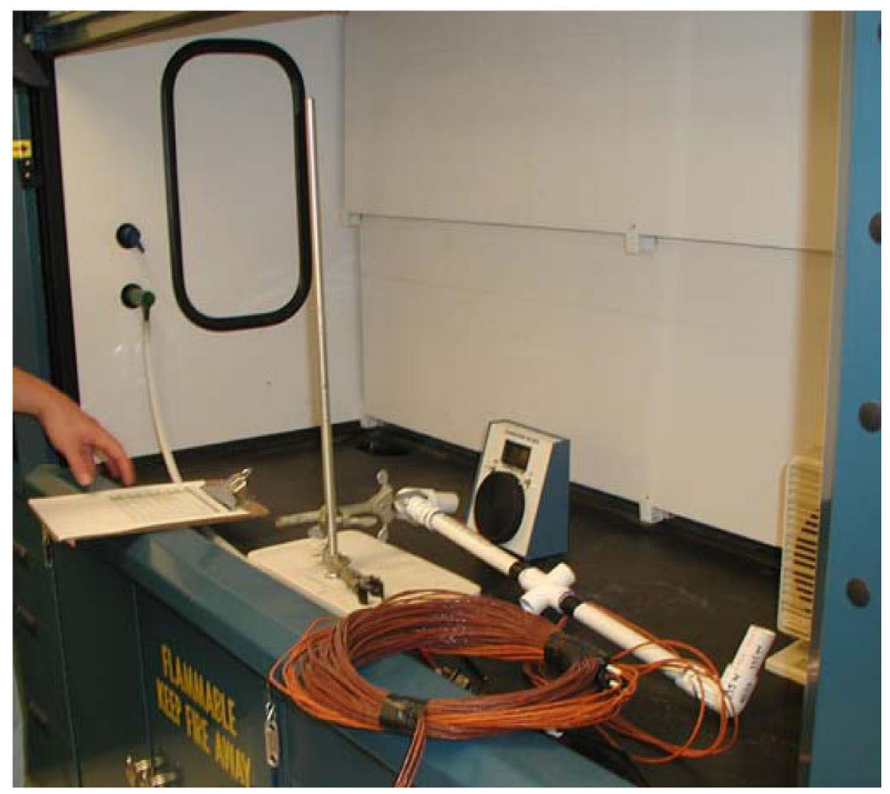

Figure 4. Calibration of infrared thermometers in the laboratory using a "black body" calibration source. 


\section{Statistical analyses and data quality control}

The statistical analyses, which included summary statistics and regression analyses were conducted using the SAS System for Windows ${ }^{\circledR}$ statistical software (SAS Institute, Inc., Cary, NC). Before the analyses, data were validated by identifying and excluding unreasonable values. For instance, data obtained during irrigation or rainfall events were excluded. Solar radiation values of less than $100 \mathrm{~W} \mathrm{~m}^{-2}$ were filtered out, which excluded data collected during nighttime, early morning, evening hours, and severely overcast conditions. Considerable differences between the canopy temperatures measured by the infrared thermometers pointing east and west on the same plot were detected during the growing season (Figure 5). These differences could be due to differences in shading of the crop canopy, differences in canopy orientations, differential cooling of the canopy as a result of changes in wind direction and solar radiation, sensor malfunction, and shift in sensor calibration. To be conservative, only data with an absolute difference of $\leq 2{ }^{\circ} \mathrm{C}$ between the canopy temperatures measured by the two sensors in each plot were retained for further analyses. In addition, the temperature values collected after the physiological maturity of the crop were excluded. Additional limits on the data were imposed to exclude data that would be unreasonable or abnormal for the area during the period of the study, including

- $5 \% \leq \mathrm{RH} \leq 100 \%$

- $0^{\circ} \mathrm{C} \leq$ air temperature $\leq 50^{\circ} \mathrm{C}$

- $0^{\circ} \mathrm{C} \leq$ canopy temperature $\leq 50^{\circ} \mathrm{C}$

- $0 \mathrm{~W} \mathrm{~m}^{-2} \leq$ solar radiation $\leq 1,300 \mathrm{~W} \mathrm{~m}^{-2}$

- $0.2 \mathrm{~m} \mathrm{~s}^{-1} \leq$ wind speed $\leq 12 \mathrm{~m} \mathrm{~s}^{-1}$

- $0 \% \leq \%$ soil water depletion in the crop root zone $\leq 100 \%$
These criteria were chosen arbitrarily and would not apply to every situation, but were expected to help filter out most of the unreasonable data during this study. The criteria were included in a computer program that was used to validate the data and to make further calculations based on the validated and filtered data.

\section{Results and discussion}

\section{Calibration of infrared thermometers}

Results of calibration for each of the infrared thermometers used in this study are shown in Figs. 6 and 7. Since correcting the infrared thermometer readings for changes in sensor body temperature using Eqs. 6-10 resulted in greater bias compared to uncorrected data, no correction for sensor body temperature was applied. Very good correlations were found between the temperature measured by the infrared sensors and the temperature of the black body calibration source as indicated by the $R^{2}$ values of 1.0 or very close to 1.0 shown in Figs. 6 and 7. The relationships, however, were better explained by a second-order polynomial function rather than a linear function. The good agreement is also indicated by the fact that readings from almost all of the sensors followed the 1:1 lines in Figs. 6 and 7. There were, however, three sensors that significantly deviated from the 1:1 line [232(T1)E, 232(T1)W, and 331(T7)E]. Since we were not sure if the calibration of these sensors was biased from the beginning of data collection or shifted during the season, data from these sensors were excluded from further analysis. These results highlight the importance of sensor calibration to obtain good quality data.

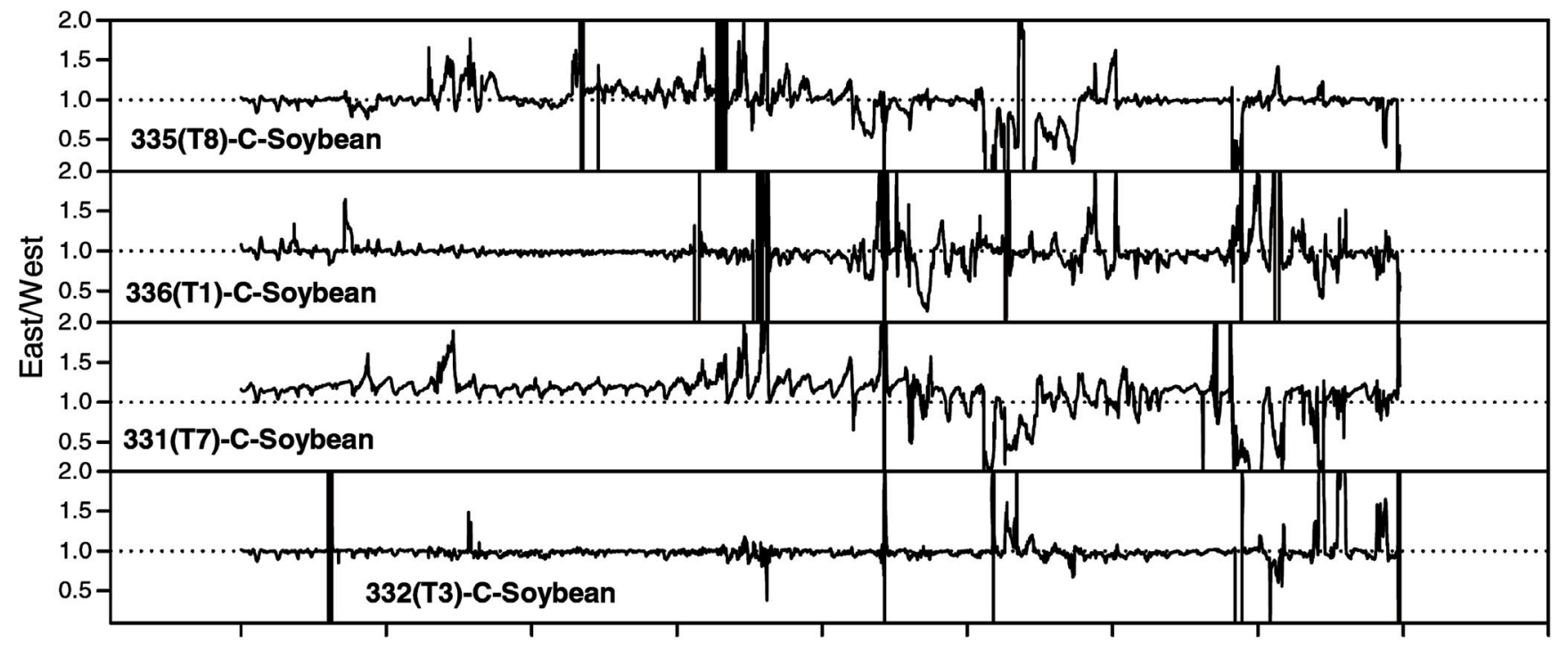

Figure 5. Ratio of canopy temperatures measured with two infrared thermometers per plot, one pointing east and the other pointing west (East/West) over four soybean plots at North Platte. The " $X$ "axis represents time from mid-July to mid-October. Each data point is a 10-min average. The label "335(T8)-C-Soybean" indicates the plot number (335), the irrigation treatment (T8), "C" means that the readings were corrected using the calibration function developed for each sensor, and "Soybean" is the crop. 
Figure 6. Calibration functions developed for each infrared thermometer used to measure canopy temperature over the corn plots. In "233(T9)E" the number "233" is the plot number, "T9" is the irrigation treatment, and " $\mathrm{E}$ " and " $\mathrm{W}$ " indicate if the infrared thermometer was pointing towards the east or west. The dashed line is the 1:1 line.

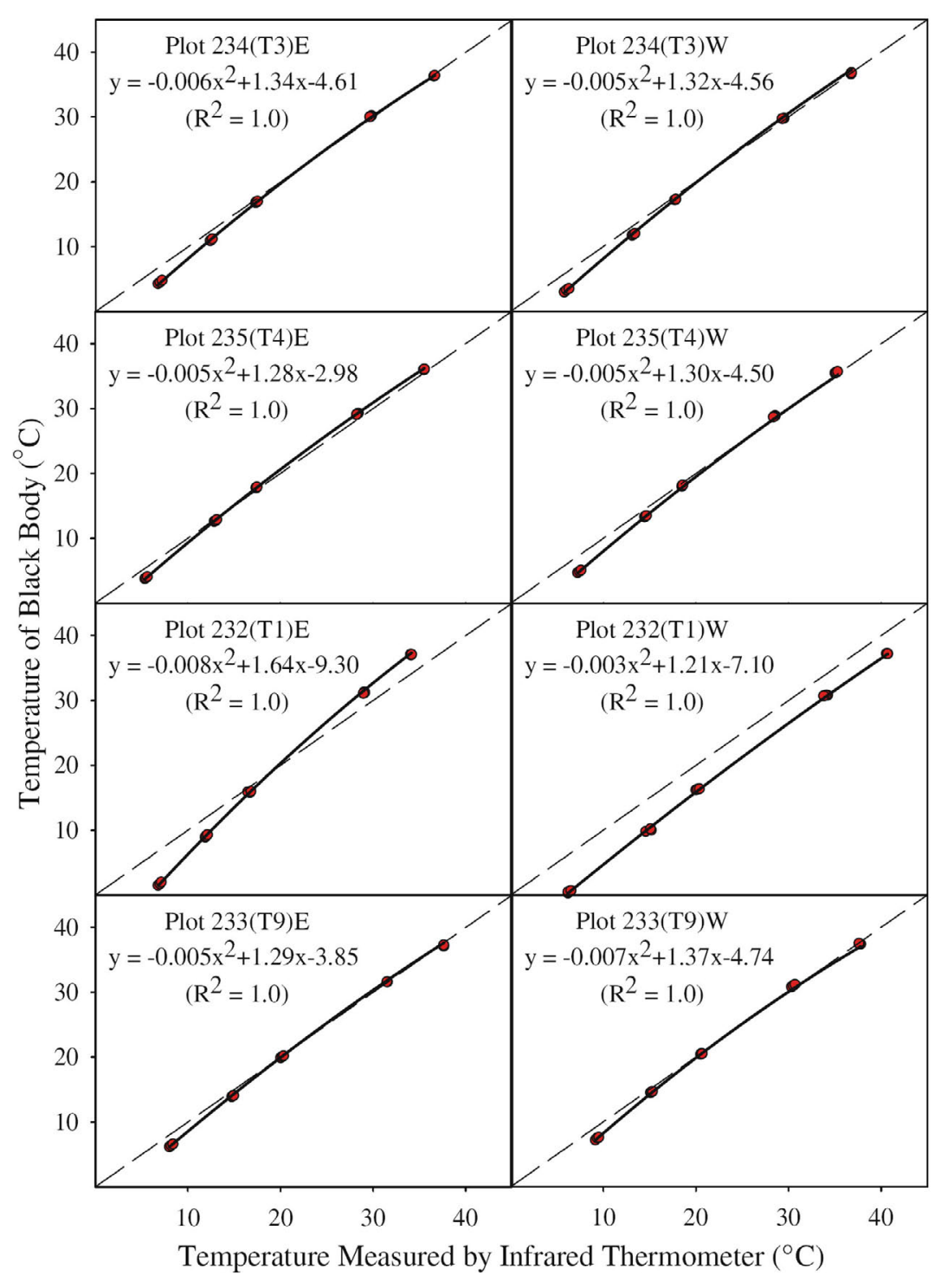

Weather conditions

Monthly averages of daily values of several weather variables (Table 3 ) show the variations in weather conditions at North Platte during the 2004 growing season. For instance, solar radiation $\left(R_{\mathrm{s}}\right)$ was similar during the months of May-September, but decreased considerably during October. Weather variables also showed significant diurnal fluctuations. For example, $R_{\mathrm{s}}$ during a clear day in the summer at North Platte can vary between $0 \mathrm{~W} \mathrm{~m}^{-2}$, just before sunrise or just after sunset, and more than $1,000 \mathrm{~W} \mathrm{~m}^{-2}$ during mid-day. The other meteorological variables also have considerable seasonal and diurnal variations, which could significantly affect the CWSI baselines. Analysis of historical weather data for the area revealed that the 2004 growing season was one of the coolest in the last decade. During May-October, the average air temperature was below the long-term average most of the time, with the exception of a few days in July. During the June-August period, the average air temperature was as much as $7-8^{\circ} \mathrm{C}$ cooler than the long-term average. The cooler air temperatures reduced crop evapotranspiration rates, which reduced crop water uptake and seasonal irrigation requirements.

Amounts and timings of individual rainfall events and the cumulative rain during the 2004 growing season at North Platte are shown in Figure 8. A total of 39 rainfall events occurred during the season, supplying a total of $414 \mathrm{~mm}$ of water, which was enough to meet more than half of the seasonal crop water requirements for corn. These conditions were wetter than normal for the area, but irrigation was still needed to match crop water requirements for both crops, especially late in the growing season.

\section{Soil water depletions in the crop root zone}

The daily $\%$ soil water depletions ( $\%$ Dep $\left._{i}\right)$ in the crop root zone for each irrigation treatment during the 2004 growing season for both crops are shown in Figure 9. For 
Figure 7. Calibration functions developed for each infrared thermometer used to measured canopy temperature over the soybean plots. In "335(T8)E" the number " 335 " is the plot number, "T8" is the irrigation treatment, and " $\mathrm{E}$ " and " $W$ " indicate if the infrared thermometer was pointing towards the east or west. The dashed line is the 1:1 line.

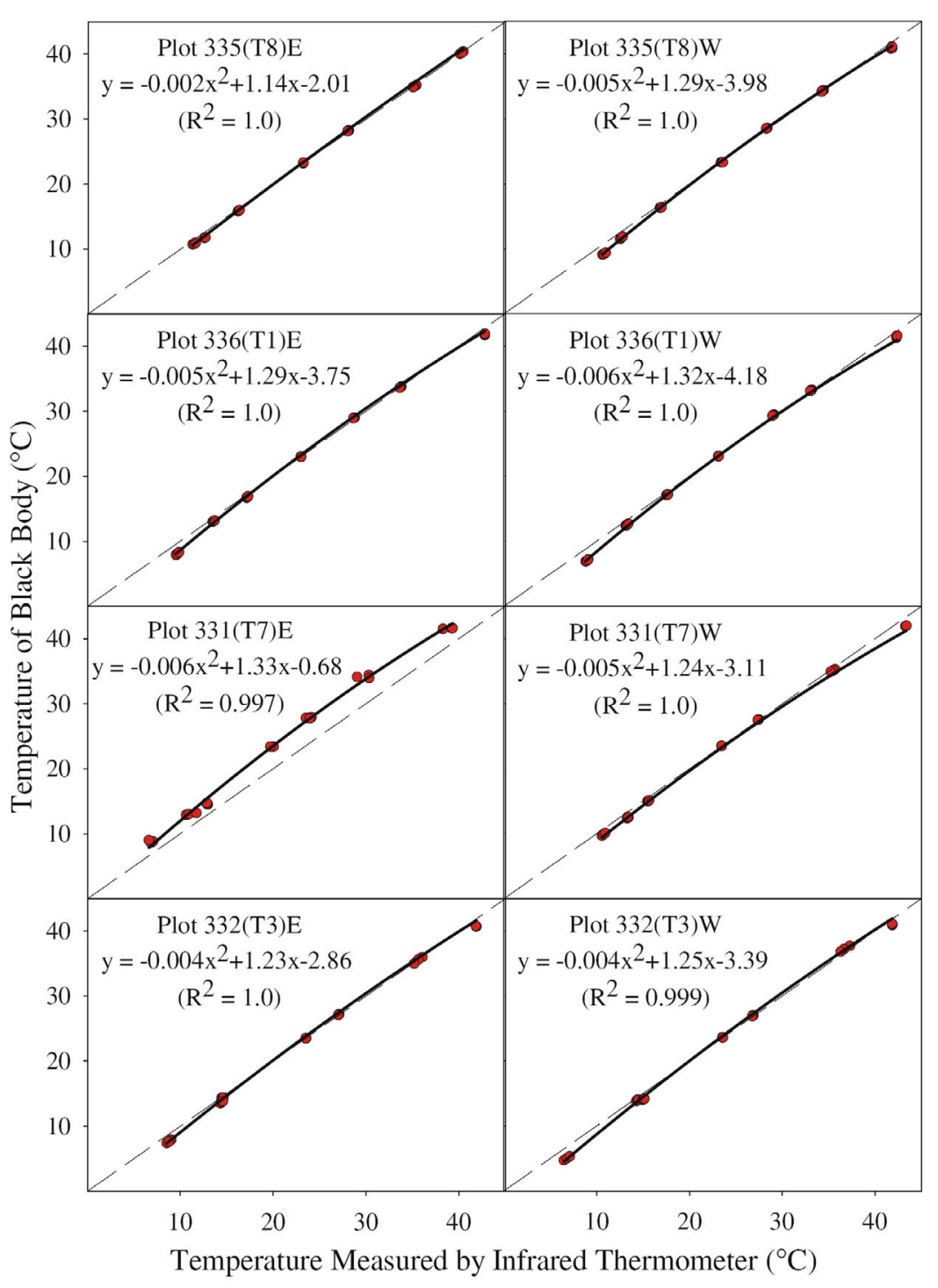

soybean, considerable differences in depletion among treatments started in August, while for corn, differences among treatments started much earlier in the season. The difference between the two crops was due to differences in water contents in the soil profile at the beginning of the season, due to irrigation treatments applied the previous year, especially for depths greater than the rooting depth of soybean. Figure 9 also shows that a variety of soil water depletion levels were observed for both crops during the study. For both crops, the wetter treatment was T1 and

Table 3. Monthly averages of daily values of several weather variables for the months of May-October at North Platte, NE, during 2004.

\begin{tabular}{|c|c|c|c|c|c|c|c|}
\hline Month & \multicolumn{7}{|c|}{ Weather variable $^{\mathrm{a}}$} \\
\hline June & 26.0 & 11.0 & 18.5 & 21.8 & 64.2 & 2.5 & 4.7 \\
\hline July & 29.8 & 14.8 & 22.3 & 22.6 & 69.3 & 2.1 & 4.9 \\
\hline August & 27.9 & 11.8 & 19.9 & 21.0 & 65.9 & 1.9 & 4.2 \\
\hline Average & 26.3 & 10.5 & 18.4 & 20.1 & 63.3 & 2.4 & 4.3 \\
\hline
\end{tabular}

a Variables are maximum air temperature $\left(T_{\max }\right)$, minimum air temperature $\left(T_{\min }\right)$, average air temperature $\left(T_{\mathrm{a}}\right)$, solar radiation $\left(R_{\mathrm{s}}\right)$, relative humidity $(\mathrm{RH})$, wind speed at 2-m height $\left(u_{2}\right)$, and grass reference evapotranspiration $\left(\mathrm{ET}_{0}\right)$ 
Figure 8. Daily and cumulative rain during the growing season at North Platte. ET $w$ is the crop evapotranspiration with no water stress.

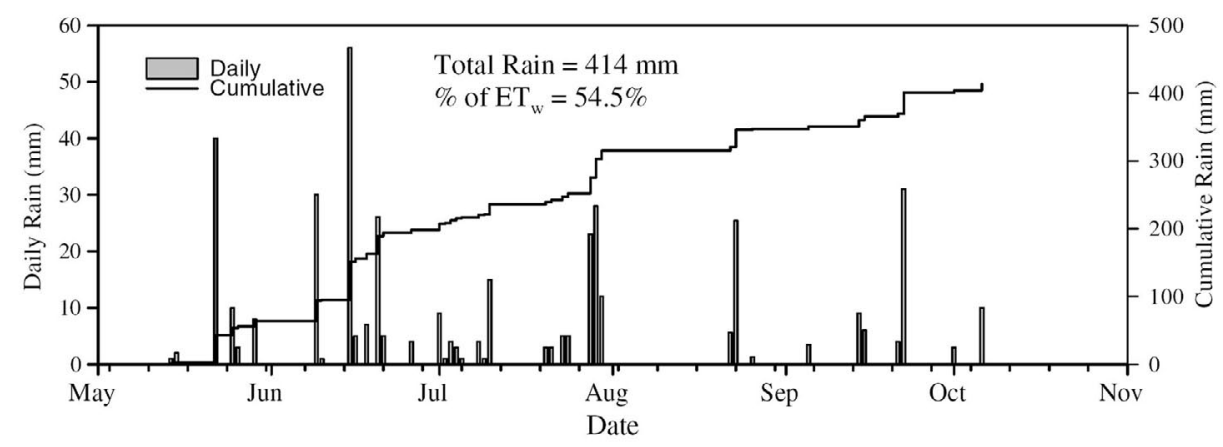

Figure 9. Daily soil water depletion in the crop root zone for different irrigation treatments (T1-T9) for corn and soybean during the 2004 growing season at North Platte, NE.

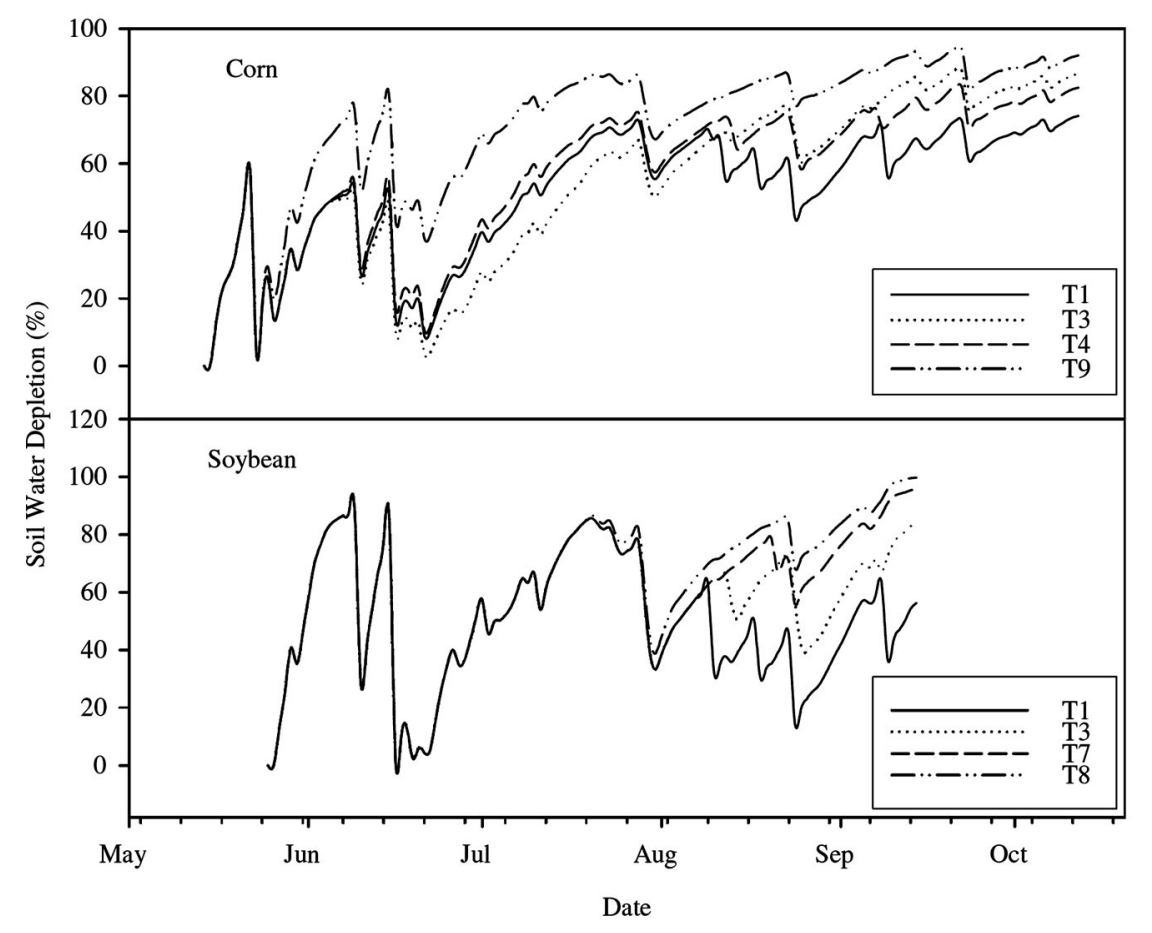

the driest was the dryland treatment (T8 for soybean and T9 for corn). Figure 9 also reflects the fact that soybean matured considerably sooner than corn. Corn maturity was delayed by approximately a month due to weather conditions that were cooler than normal for North Platte.

\section{Upper and lower CWSI baselines}

After validating the data using the filtering criteria described above, a total of 9,468 and 3,315 data points (10min averages) were retained for analyses for corn and soybean, respectively. Summary statistics for the data retained for analysis are given in Table 4 . Statistics include the mean, standard deviation, minimum, and maximum values for nine variables used in the analyses. After the data were validated, equations for the upper and lower CWSI baselines were developed using multiple regression analysis. The equation for the upper baseline for each crop was developed by including only data with $\% \operatorname{Dep}_{i}>85 \%$, which indicated that the crops were under severe water stress. To develop the equation for the lower baseline, only data with $\% \mathrm{Dep}_{i}<50 \%$, for soybean, and $\% \operatorname{Dep}_{i}<55 \%$, for corn were included in the analysis. These values were considered as indicative of non-waterstress conditions, with plants transpiring at the potential rate, and were taken from Table 22 in FAO-56 (Allen et al. 1998). All of the measured variables that could have an effect on the baselines were originally included in the multiple regression analysis. However, only those variables that were statistically significant $(P<0.05)$ were included in the final multiple regression equations.

The multiple regression analyses for both crops and for the upper and lower baselines resulted in $R^{2}$ values ranging from 0.69 to 0.84 (Table 5). The lower baselines for both crops were functions of $h, \mathrm{VPD}, R_{\mathrm{s}^{\prime}}$ and $u$. The upper baselines did not depend on VPD, but were a function of 
Table 4. Summary statistics of data included in the analyses.

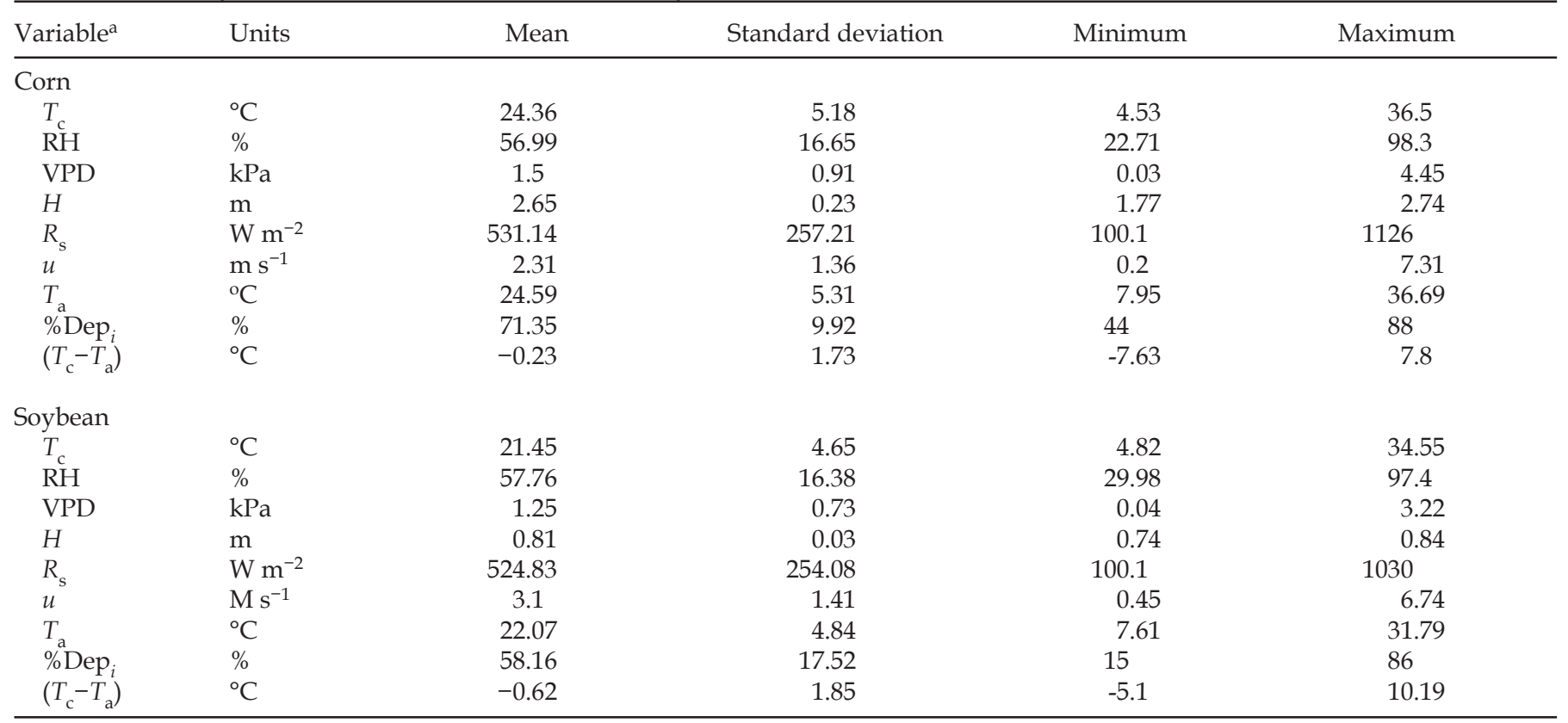

aVariables are canopy temperature $\left(T_{c}\right)$, air temperature $\left(T_{\mathrm{a}}\right)$, vapor pressure deficit (VPD), canopy height $(h)$, solar radiation $\left(R_{\mathrm{s}}\right)$, wind speed $(u)$, soil water depletion in the crop root zone $\left(\% \mathrm{Dep}_{i}\right)$, and $n$ is the number of data points included in the analysis $(n=9,468$ for corn and 3,315 for soybean). Wind speed was measured at a height of 3.7 and $2.0 \mathrm{~m}$ above ground in the corn and soybean plots, respectively.

$R_{\mathrm{s}}$ and $u$ for soybean, and $R_{\mathrm{s}^{\prime}} h$, and $u$ for corn. It should be kept in mind, however, that the baselines were empirically determined for specific ranges of environmental and crop conditions as specified in Table 4, and therefore the equations should only be applied within these ranges.

The upper and lower baselines for corn and soybean calculated using the equations in Table 5 are plotted in Figure 10, assuming specific values for solar radiation, wind speed, and plant canopy height. Figure 10 shows that the baselines developed in this study are consistent with the theoretical approach of Jackson et al. (1981) and Jackson (1982), in the sense that the lower baseline has a negative slope when plotted as a function of VPD, while the slope of the upper baseline is zero. For the conditions assumed in Figure 10 for corn and soybean, the lower baselines were very similar for both crops, and the upper baseline for soybean was about $1^{\circ} \mathrm{C}$ greater than for corn.

When upper and lower baselines for corn that were developed by other researchers were examined earlier (Figure 1), it was found that there are considerable differences among the baselines developed for the same crop. These results might be due to the fact that they only considered VPD and did not take into account other variables such as solar radiation, wind speed, and canopy height that significantly affect the baselines. However, the significant differences in intercepts and slopes of the baselines in Figure 1 indicate that using only these variables may not be enough when developing universal non-water stressed baselines. For example, the non-water stressed baseline developed by Idso (1982) had an intercept of approximately $0.5^{\circ} \mathrm{C}$, whereas the baseline developed by Yazar et al. (1999) had an intercept of approximately $-1.5^{\circ} \mathrm{C}$. The difference between the two baselines is $2^{\circ} \mathrm{C}$. Thus, for a given change in VPD, different $\left(T_{c}-T_{a}\right)$ values are obtained. When the CWSI is used for irrigation scheduling, this $2^{\circ} \mathrm{C}$ difference will cause considerable errors when determining irrigation timing and critical allowable stress level. In other words, for the same location, using the different baselines in Figure 1 to schedule irrigation for corn would result in different irrigation timing.

Table 5. Upper and lower baselines for corn and soybean determined at North Platte during 2004.

\begin{tabular}{lllrl}
\hline Baselines & Depletion (\%) & Equations for Corn ${ }^{\mathrm{a}}$ & $R^{2}$ & \\
\hline Upper baseline & $>85$ & $T_{\mathrm{c}}-T_{\mathrm{a}}=-19.51+6.71 h+0.0044 R_{\mathrm{s}}-0.26 u$ & 831 & 0.69 \\
Lower baseline & $<55$ & $T_{\mathrm{c}}-T_{\mathrm{a}}=3.0-1.96 h-1.66 \mathrm{VPD}+0.0041 R_{\mathrm{s}}+0.296 u$ & 524 & \\
& & Equations for soybean & & \\
\hline Upper baseline & $>85$ & $T_{\mathrm{c}}-T_{\mathrm{a}}=-2.53+0.0074 R_{\mathrm{s}}-0.31 u$ & 281 & 0.81 \\
Lower baseline & $<50$ & $T_{\mathrm{c}}-T_{\mathrm{a}}=-3.63+2.95 h-1.95 \mathrm{VPD}+0.0043 R_{\mathrm{s}}-0.148 u$ & 1659 \\
\hline
\end{tabular}

${ }^{a}$ The baselines were determined by multiple regression analysis. Variables and units are canopy temperature $\left(T_{\mathrm{c}^{\prime}}{ }^{\circ} \mathrm{C}\right)$, air temperature $\left(T_{\mathrm{a}^{\prime}}{ }^{\circ} \mathrm{C}\right)$, vapor pressure deficit $(\mathrm{VPD}, \mathrm{kPa})$, canopy height $(h, \mathrm{~m})$, solar radiation $\left(R_{\mathrm{s}^{\prime}} \mathrm{W} \mathrm{m}^{-2}\right)$, wind speed $\left(u, \mathrm{~m} \mathrm{~s}^{-1}\right)$, and $n$ is the number of data pairs included in the analysis. Wind speed was measured at a height of 3.7 and $2.0 \mathrm{~m}$ above ground in the corn and soybean plots, respectively. 


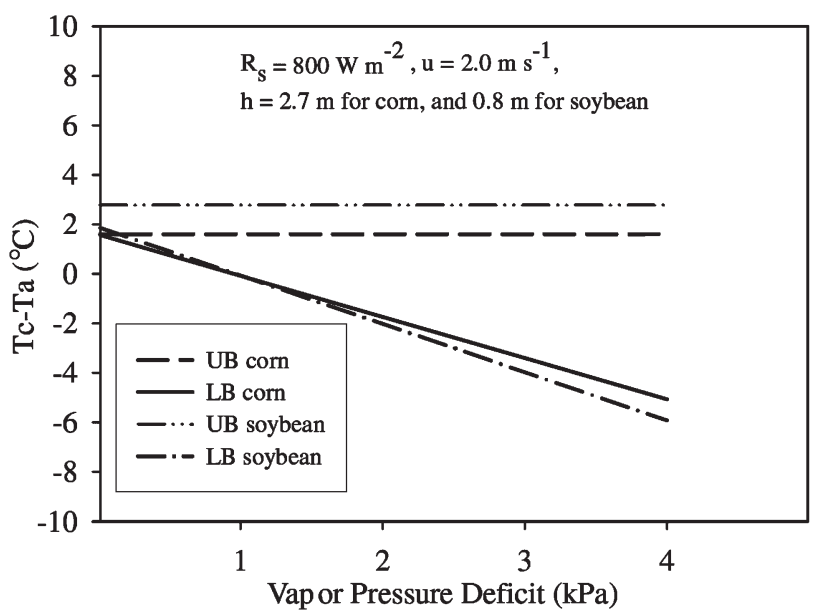

Figure 10. Upper and lower baselines (UB and LB) for corn and soybean for the conditions shown, calculated using equations in Table 5. $R_{\mathrm{s}}=$ solar radiation, $u=$ wind speed, $h=$ plant canopy height, $T_{c}=$ canopy temperature, and $T_{a}=$ air temperature. Wind speed was measured at a height of 3.7 and $2.0 \mathrm{~m}$ above ground in the corn and soybean plots, respectively.

Taking plant height into account when developing baselines is actually more important than it seems and has not received enough attention by other researchers. Idso (1982) pointed out that taking canopy development into account when developing baselines would help reduce errors associated with natural spatial variability of field crops. For example, the baselines for the same crop may shift significantly as the crop changes from the vegetative to the reproductive stage. Idso (1982) pointed out this phenomenon for wheat and barley when he observed a less steep slope during the post-heading stage and implied that there was a greater effective canopy diffusion resistance than for the pre-heading stage. Thus, he observed that for a given change in VPD, more transpira- tional cooling occurred in the pre-heading stage than in the post-heading stage, causing a change in the baselines. These observations by Idso (1982) highlight the importance of taking into account some plant growth indicator, such as plant height, to develop more representative baselines. Plant height also affects the crop aerodynamic resistance, which has been shown to affect the baselines (Jackson et al. 1981). It also affects other energy balance components such as soil heat flux (Payero et al. 2005b), surface albedo (Payero et al. 2005c), and canopy reflectance (Payero et al. 2004) that could affect air and canopy temperatures, and therefore, a shift in the baselines.

Information about the diurnal variation of the CWSI baselines is lacking. Figure 11 shows the baselines calculated every $10 \mathrm{~min}$ with the equations developed in this study for corn and soybean. The baselines had significant variations as a response to diurnal and day-today changes in weather conditions. For both baselines and crops, a diurnal change in $\left(T_{\mathrm{c}}-T_{\mathrm{a}}\right)$ of approximately $5^{\circ} \mathrm{C}$ was typical under the conditions of this study. When daily and diurnal fluctuations in weather variables are considered, taking into account variables such as solar radiation and wind speed results in more realistic baselines. Although, including these variables in the equations would require additional measurements, improved accuracy should be more important than the difficulties in gathering additional data.

\section{Conclusions}

In this study, equations to estimate the upper and lower CWSI baselines were developed for corn and soybean. The lower baselines for both crops were functions of $h, \mathrm{VPD}, R_{\mathrm{s}^{\prime}}$ and $u$. The upper baselines did not depend on VPD, but were a function of $R_{\mathrm{s}}$ and $u$ for soybean, and $R_{\mathrm{s}^{\prime}} h$, and $u$ for corn. By taking into account all the vari-
Figure 11. Calculated lower and upper crop water stress index (CWSI) baselines for corn and soybean at North Platte. The " $X$ " axis represents time from August 8 to August 28, 2004. During the period, plant canopy height (h) for corn ranged 2.36$2.74 \mathrm{~m}$, and $0.76-0.84 \mathrm{~m}$ for soybean. Each point represents a $10-\mathrm{min}$ average obtained during daytime.

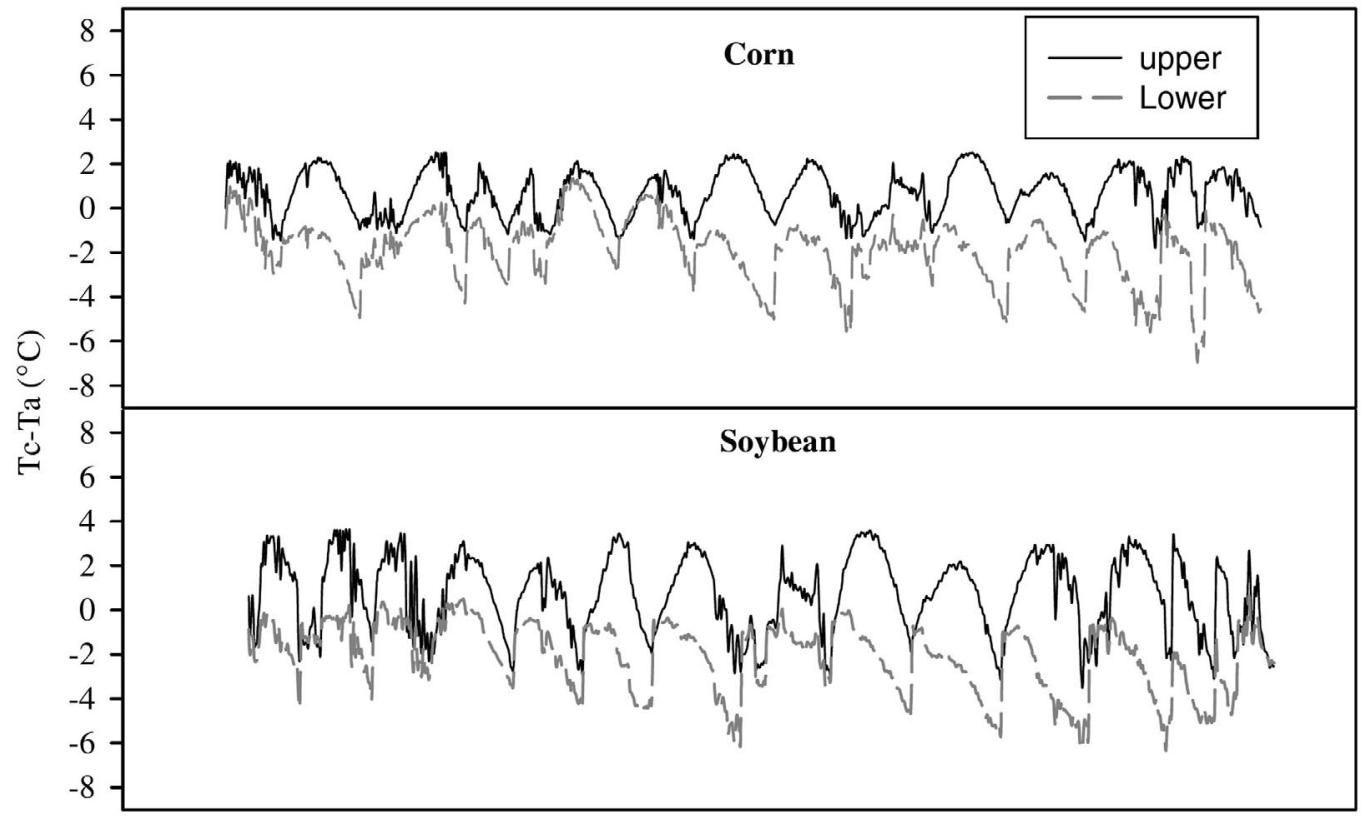


ables that significantly affect the baselines, it should be possible to apply them at different times of the day and at different locations for the same crop. The new baselines developed in this study should enhance the application of the CWSI method for irrigation scheduling of corn and soybean, although there is still a need for additional validation of the equations by repeating the experiment in other environments and in other growing seasons. There is also a need for further studies to investigate the relationships between CWSI and soil water depletion in the crop root zone, especially focusing on the diurnal variations of these variables.

Acknowledgments - A contribution of the University of Nebraska Agricultural Research Division, Lincoln, NE 68583, Journal Series No. 15029. Partial funding for this project was provided by the USGS. Commercial names are provided only for the convenience of the reader and do not imply endorsement by the authors or by the University of Nebraska-Lincoln.

\section{References}

Allen RG, Pereira LS, Raes D, Smith M (1998) Crop evapotranspiration-guidelines for computing crop water requirementsFAO Irrigation and Drainage Paper No. 56. Rome, Italy: FAO

Alves I, Pereira LS (2000) Non-water-stressed baselines for irrigation scheduling with infrared thermometers: a new approach. Irrig Sci 19(2):101-106

Blad BL, Gardner BR, Watts DG, Rosenberg NJ (1981) Remote sensing of crop moisture status. Remote Sens Q 3:4-20

Bugbee B, Droter M, Monje O, Tanner B (1998) Evaluation and modification of commercial infra-red transducers for leaf temperature measurement. Adv Space Res 22(10):1425-1434

Carlson RE, Yarger DN, Shaw RH (1972) Environmental influences on the leaf temperatures of two soybean varieties grown under controlled irrigation. Agron J 64(2):224-229

Conaway J, van Bavel CHM (1967) Evaporation from a wet soil surface calculated from radiometrically determined surface temperatures. J Appl Meteorol 6(4):650-655

Ehrler WL (1973) Cotton leaf temperatures as related to soil water depletion and meteorological factors. Agron J 65(3):404-409

Ehrler WL, Idso SB, Jackson RD, Reginato RJ (1978) Wheat canopy temperature: relation to plant water potential. Agron J 70(2):251-256

Fuchs M, Tanner CB (1966) Infrared thermometry of vegetation. Agron J 58(6):597-601

Gates DM (1964) Leaf temperature and transpiration. Agron J 56(3):273-278

Geiser KM, Slack DC, Allred ER, Stange KW. 1982. Irrigation scheduling using crop canopy-air temperature difference. Trans ASAE 25(3):689-694

Idso SB. 1982. Non-water-stressed baselines: a key to measuring and interpreting crop water stress. Agric Meteorol 27(1):59-70

Idso SB, Jackson RD, Reginato RJ (1977) Remote sensing of crop yields. Science 196:19-25

Idso SB, Jackson RD, Pinter PJ, Hatfield JH (1981) Normalizing the stress-degree-day parameter for environmental variability. Agric Meteorol 24(1):45-55

Irmak S, Haman DZ, Bastug R (2000) Determination of crop water stress index for irrigation timing and yield estimation of corn.
Agron J 92(6):1221-1227

Jackson RD (1982) Canopy temperature and crop water stress. In: Hillel D (ed) Advances in irrigation. Academic, New York, pp 43-85

Jackson RD, Reginato RJ, Idso SB (1977) Wheat canopy temperature: a practical tool for evaluating crop water requirements. Water Resour Res 13(3):651-656

Jackson RD, Idso SB, Reginato RJ, Pinter PJ (1981) Canopy temperature as a crop water stress indicator. Water Resour Res 17(4):1133-1138

Jensen HE, Svendsen H, Jensen SE, Mogensen VO (1990) Canopyair temperature of crops grown under different irrigation regimes in a temperate humid climate. Irrig Sci 11:181-188

Johnson B (2001) Inventorying Nebraska's irrigation acres. Cornhuskers Economics. University of Nebraska Cooperative Extension, June 20, 2 pp

Klocke NL, Watts DG, Schneekloth JP, Davison DR, Todd RW, Parkhurst AM (1999) Nitrate leaching in irrigated corn and soybean in a semi-arid climate. Trans ASAE 42(6):1621-1630

Linacre ET (1964) A note on a feature of leaf and air temperatures. Agric Meteorol 1(1):66-72

Nielsen DC, Gardner BR (1987) Scheduling irrigation for corn with the crop water stress index (CWSI). Appl Agric Res 2(5):295-300

Payero JO, Neale CMU, Wright JL (2004). Comparison of eleven vegetation indices for estimating plant height of alfalfa and grass. Appl Eng Agric 20(3):385-393

Payero JO, Neale CMU, Wright JL (2005a) Non-water-stressed baselines for calculating crop water stress index (CWSI) for alfalfa and tall fescue grass. Trans ASAE 48(2):653-661

Payero JO, Neale CMU, Wright JL (2005b) Estimating soil heat flux for alfalfa and clipped tall fescue grass. Appl Eng Agric 21(3):401-409

Payero JO, Neale CMU, Wright JL (2005c) Near-noon albedo values of alfalfa and tall fescue grass derived from multi-spectral data. Int J Remote Sens (in press)

Postel S (1999) Pillar of sand: can the irrigation miracle last?, 1st edn. W.W. Norton \& Company, New York

Sadler EJ, Bauer PJ, Busscher WJ, Millen JA (2000) Site-specific analysis of a droughted corn crop: II. Water use and stress. Agron J 92(3):403-410

Shanahan JF, Nielsen DC (1987) Influence of growth retardants (Anti-Gibberellins) on corn vegetative growth, water use, and grain yield under different levels of water stress. Agron J 79(1):103-109

Stegman EC (1986) Efficient irrigation timing methods for corn production. Trans ASAE 29(1):203-210

Steele DD, Stegman EC, Gregor BL (1994) Field comparison of irrigation scheduling methods for corn. Trans ASAE 37(4):1197-1203

Wolpert A (1962) Heat transfer analysis of factors affecting plant leaf temperature: significance of leaf hair. Plant Physiol 37(2):113-120

Wright JL (1982) New evapotranspiration crop coefficients. J Irrig Drainage Div, ASCE 108:57-74

Yazar A, Howell TA, Dusek DA, Copeland KS (1999) Evaluation of crop water stress index for LEPA irrigated corn. Irrig Sci 18(4):171-180

Zolnier S, Gates RS, Anderson RG, Nokes SE, Duncan GA (2001) Non-water-stressed baseline as a tool for dynamic control of misting system for propagation of poinsettias. Trans ASAE 44(1):137-147 